\title{
Counter-Evidence of ASEAN Stock Market Efficiency
}

\author{
Abdul Razak Abdul Hadi ${ }^{1} \&$ Eddy Tat Hiung Yap ${ }^{1}$ \\ ${ }^{1}$ Business School, Universiti Kuala Lumpur, Malaysia \\ Correspondence: Eddy Tat Hiung Yap, Business School, Universiti Kuala Lumpur, Bangunan Yayasan Selangor, \\ Jalan Raja Muda Abdul Aziz, 50300, Kuala Lumpur, Malaysia. E-mail: eddythyap@gmail.com
}

Received: April 7, 2015

Accepted: May 3, 2015

Online Published: June 25, 2015

doi:10.5539/ijef.v7n7p207

URL: http://dx.doi.org/10.5539/ijef.v7n7p207

\begin{abstract}
The objective of this paper is to investigate the effects of variations in crude oil price and the macroeconomic variables of consumer price index, exchange rates and money supply on ASEAN stock market performance. The Efficient Market Hypothesis (EMH) is used as the theoretical framework where stock market prices are hypothesized to be fully reflective of all available information and hence could not be forecasted by any macroeconomic variable. Both static and dynamic panel data analysis were used to investigate monthly data from January 1997 to December 2013. Results show that crude oil price and macroeconomic variables have significant leading effect on ASEAN stock market performance, and as such, contradict the validity of EMH in collective ASEAN stock markets.
\end{abstract}

Keywords: ASEAN, stock market, efficient market hypothesis, macroeconomic variables, panel data analysis

\section{Introduction}

The aim of this article is to investigate the Efficient Market Hypothesis (EMH) for the Association of Southeast Asian Nations' (ASEAN) stock markets for the period January 1997 to December 2013. We test whether these markets are efficient individually and collectively using a number of statistical tests, and including crude oil price as an independent variable along with other macroeconomic variables of consumer price index, exchange rate and money supply.

ASEAN is the sub-regional grouping of the largest continent in the world with total nominal gross domestic product (GDP) of USD2.3 trillion in 2012, and is represented by 10 countries, of which the four countries of Malaysia, Indonesia, Thailand and Singapore, contributing $80 \%$ of the total GDP for this region, are selected for detailed investigation on the basis of their geographical proximity and diversity in the political, sociological and economic landscape. ASEAN is also chosen to help bridge the current academic gap where majority of research is still focused on developed countries.

Stock market indices are leading indicators of the general economy as it is deemed a barometer of the state of the economy, due to its sensitivity and susceptibility to both information and disinformation. As the current stock market prices factor in the future outlook of the macro economy, industry and the company in particular, it bears important policy implications being a predictor of the economy as market prices appears faster than the publishing of economic data. There has been extensive studies with various permutations performed in the study of the stock market but there are still no conclusive results to validate the Efficient Market Hypothesis (EMH) (Fama, 1965), where various interpretations on the efficiency of stock markets persist.

Energy studies, more notably crude oil price and consumption, has gained importance as energy needs are increasing due to rising population, industrialization and affluence, with crude oil as the most important natural energy resource that fuels many industries and hence powers the global economy. It served as an oracle of sorts when the global economy crashed in 2008 where it was preceded by the all-time high in crude oil price of USD147 in July 2008. Crude oil price remains a key indicator relevant to many policy and business decisions even as efforts are made to diversify energy supplies from renewable sources. The three largest economies in the world: the United States, China and Japan, are large consumers of oil and are net oil importers. Many energy studies are centered on these countries, and less on developing nations which allows room for more academic investigations to fill this gap. 


\section{Literature Review}

\subsection{ASEAN Stock Market}

Market efficiency has important repercussions for investors who seek to identify assets to invest in the equity markets. If the equity market is efficient, attempts to find mispriced assets to make excess returns would not yield any extra ordinary returns. In efficient markets, asset prices reflect the best estimate that investors make with regards to the expected risk and the expected return of the assets. Therefore, there are no undervalued assets offering higher than expected returns or overvalued assets offering lower than expected returns as all assets in the market will be appropriately priced offering optimal reward to risk in an efficient market. Conversely, in inefficient markets, investors can enhance returns by identifying and investing in mispriced assets. EMH thus functions as a theoretical and predictive model of operations of the financial markets.

Our study aims to investigate the EMH for a selected sample of countries, which are members of ASEAN. There are specific reasons to consider the ASEAN member countries. ASEAN as an economic block is gaining credibility and researchers and policy makers are increasingly considering these markets in their studies of market integration and financial market development. It was decided in 2010 for ASEAN to develop a roadmap for financial integration ASEAN countries by 2015, which involves the development of capital markets with a long-term goal of achieving higher cross-border integration along the lines of the European Union. One necessary condition for investors to have incentive in allocating capital across the ASEAN stock markets is market efficiency. An efficient market is supposed to provide accurate signals for the allocation of capital and real investments such as foreign direct investments (FDI). Considering that the economic development of the ASEAN economies relies heavily on FDI, it is clear that the lack of stock market efficiency may delay the overall process of growth by providing a disincentive to invest in these markets.

Overall research on Asian stock markets showed mixed results. EMH was frequently rejected in these studies where markets were shown to be inefficient while using daily frequency data. However, these studies show that stock prices adhere to EMH when lower frequency data such as monthly and quarterly data were used. Most of these studies utilise the Variance Ratio (VR) test of Lo and MacKinlay $(1988,1989)$. However, as pointed out by Wright (2000), nonparametric-based tests are more effective than traditional VR tests, which may provide inconsistent results for different sampling periods. In order to consider this problem, some studies have used the Multiple VR (MVR) test of Chow and Denning (1993), which allows for testing the behaviour of stock prices through different intervals of time. A number of studies such as Karemera et al. (1999); Chang and Ting (2000); Buguk and Brorsen (2003); Chang et al. (2004); Hoque et al. (2007); Fifield and Jetty (2008); Lagoarde and Lucey (2008); Hung (2009), analysed the EMH for Asian stock markets, with results showing that Asian stock markets are characterized by a certain degree of predictability, especially when daily data are considered. However, applying the conventional VR test in cases when data are not normally distributed may lead to high acceptance rates for the null hypothesis of random walk. To overcome that problem, some authors have preferred using the MVR tests. Use of MVR tests provides more robust results given that it also considers the presence of heteroscedasticity. On the other hand, as pointed out by Charles and Darne (2009), splitting a sample of data in sub-periods and applying the MVR test to each sub-sample may lead to asymmetric results where the EMH may be found only in more recent periods. This may be explained with the evolving regulatory environment of stock markets such as the liberalisation on trading restrictions. Using Wright's non-parametric test, Kim and Shamsuddin (2008) and Charles and Darne (2009) found higher rates of rejection of the EMH i.e. market inefficiency.

It is evident from the review of the literature that a mix of different results has been achieved by using different methods, different datasets and different time periods. Ongoing liberalization processes and removal of trading restrictions taking place in ASEAN stock markets may explain to a certain extent the asymmetrical results. In this study, we employ a number of panel data analysis (i.e. pooled ordinary least squares (OLS), Fixed One Way, Fixed Two Way, Random One Way, Random Two Way, Parks and Da Silva) in order to investigate whether the ASEAN stock markets are efficient individually and collectively. Panel data analysis is selected as it is deemed more advanced and robust due to its combination of time-series and cross-sectional nature.

\subsection{Energy Market}

Many researches indicate that there is an inverse relationship between oil price increase and aggregate economic activity. These studies were spurred by the first oil crisis in 1973, where Pierce and Enzler (1974) noted the inverse relationship, followed by Rasche and Tatom (1977), Mork and Hall (1980) and Darby (1982). Hamilton (1983) subsequently produced the seminal study on oil shocks, where he observed that all but one post-war recessions had been preceded by a sharp rise in oil price. It was oil price increase that caused the recessions. These oil shocks 
affect the macroeconomy primarily by depressing demand for consumption and investment. Gisser and Goodwin (1986) and Mork (1989) confirmed the findings of Hamilton using alternative data and estimation procedures. Lee et al. (1995) worked from the angle of oil price volatility and found that it significantly affects the gross national product. They found that oil price shocks have a greater impact on the economy during long periods of stability, compared to volatile environments. In some cases, the effects have been shown to be asymmetric where oil price increases depress the economy, but oil price decreases do not lift the economy by similar proportions (Sadorsky, 1999; Ferderer, 1996; Mork, 1989). Lee and Ni (2002) subsequently found that oil shocks also reduce demand in other industries, especially the automobile industry. Yang et al. (2002) found that higher oil prices yield subsequent recessions in oil consuming nations. Tang et al. (2010) found an oil-price increase negatively affects output and investment, but positively affects inflation rate and interest rate. This study allowed for a gap in research on impact of oil prices on oil producing nations.

However, most studies in the literature have focused on the economy of the United States, the largest oil importer and largest economy in the world, rather than oil-exporting and developing countries. The impact of oil price shocks on the national economies of oil-exporting countries could be different from those of oil-importing countries and this raises concern that existing literature is not exhaustive.

Although higher oil prices may induce increases in industry costs and inflation rates, as well as a reduction of expenditure on non-oil goods (Barsky \& Kilian, 2004) in oil-importing countries, they may generate more income for oil-exporting countries due to the low price elasticity of crude oil demand (e.g., Bjørnland, 2009; Jung \& Park, 2011). Given this heterogeneity, this paper focus on the effects of oil price movements on stock markets in both net oil-importing (Indonesia and Thailand) and net oil-exporting (Malaysia) countries, including a total oil-importing (Singapore) country.

\subsection{Stock Market and Energy Market}

A large body of research contributes to the analysis of relationship between changes in oil prices and stock market returns. There is a consensus among these studies about the existence of negative relationship between oil prices and stock market activities (Basher et al., 2012; Chen, 2010; Elder \& Serletis, 2010; Jones \& Kaul, 1996; Kilian \& Park, 2009; Masih et al., 2011; Sadorsky, 1999; Wei, 2003), although some studies show that the impact of oil price changes on stock markets is not always as significant as hypothesized e.g., Huang et al. (1996); Apergis and Miller (2009); Miller and Ratti (2009). Studies on oil-exporting countries can be found in few studies, where Bjørnland (2009) shows that a $10 \%$ increase in oil price can result in an approximately $5 \%$ increase in stock prices in Norway.

Park and Ratti (2008) also find that increases in oil prices have positive effects on the Norwegian stock market, in contrast to those in oil-importing countries where increases in oil prices have negative effects. Jung and Park (2011) compared the significance of response to oil supply and demand shocks by stock markets in an oil-exporting country (Norway) and an oil-importing country (Korea) with the finding that the response of stock market returns to oil price shocks in these two countries differ greatly to each other. Overall, the results in these three studies indicate that the impacts of oil price shocks on stock markets in oil-exporting and oil importing countries are heterogeneous to each other.

One limitation of the above-mentioned studies is that they focus only on a single oil-exporting country (Norway) or on developed countries. Some countries produce and export more crude oil than Norway (e.g., Saudi Arabia and Russia), and several emerging economies such as China and India as consumers may be more responsible for the oil price increases in recent years (e.g., Hamilton, 2009; Kilian, 2009).

Another literature gap identified is that although there are a number of studies on the relationship between oil price and stock market returns, fewer studies examined the impact of oil price uncertainty on stock markets (Park \& Ratti, 2008; Elder \& Serletis, 2010; Masih et al., 2011). A common limitation of previous studies on this issue is that they only focus on oil-importing economies and do not differentiate the effects of aggregate demand and supply uncertainty.

For this paper, as a proxy for stock market, we use the major stock index for each of the countries: KLCI (Malaysia), JCI (Indonesia), SET (Thailand), and STI (Singapore). As a proxy for world oil price level, we use the monthly price data of West Texas Intermediate (WTI) crude oil. WTI oil price is primarily used in the United States and widely used internationally as the benchmark for oil pricing, and is highly correlated with the prices for other two major categories of crude oil, Brent Blend (primarily used in Europe and OPEC) and Dubai Crude.

\subsection{Macroeconomic Variables}

In researches on country exchange rates, for export dominant countries, there is a negative relationship as home currency appreciation would lower its competitiveness due to higher selling prices in the destination country. For 
import dominant countries, there is a positive relationship as demonstrated by Mukherjee and Naka (1995), Maysami and Koh (2000) and Ibrahim and Aziz (2003) with the assertion that home currency appreciation reduces overall costs.

In studies of inflation, there is positive relationship between consumer price index and stock market returns as found by Abdullah and Hayworth (1993), Khil and Lee (2000), Ibrahim and Aziz (2003), Shabri et al. (2001) and Ibrahim (2003) because stocks are used as hedge against inflation. There is however a negative relationship between consumer price index and stock market returns as shown by Fama and Schwert (1977), Fama (1981), Schwert (1981), Solnik (1983), Gultekin (1983), Geske and Roll (1983), Chen et al. (1986), DeFina (1991) and Mukherjee and Naka (1995) due to increase in cost of production and increase in nominal risk-free rate of return.

In studies of money supply, theoretically there is negative relationship between money supply and stock returns because increase in money supply may raise expectations of inflation and thus raises the interest rate, which would reduce corporate profitability. However, positive relationship were shown between money supply and stock returns by Abdullah and Hayworth (1993), Mukherjee and Naka (1995) because increase in money supply increases liquidity in the economy (creating encouragement in the economy), leading to lower interest rates.

\section{Methodology}

The EMH was widely accepted until the 1990s, when behavioral economists provided alternative methods of analysing the stock market. Empirical analyses have consistently found problems with the EMH as stocks of low price-earning ratio are found to be outperforming other stocks. Alternative theories have proposed that cognitive biases cause these inefficiencies, leading investors to purchase overpriced growth stocks rather than value stocks. Although the EMH has become controversial because substantial and lasting inefficiencies are observed, Beechey (2000) consider that it remains a worthwhile starting point for studies on stock market performance.

The efficient-market hypothesis emerged as a prominent theory in 1965 when Fama (1965) published his dissertation arguing for the random walk hypothesis with Samuelson (1965) subsequently publishing a proof for an enhanced version of the EMH. Fama (1970) reviewed both the theory and the evidence for the EMH to include the definitions for three forms of financial market efficiency: weak, semi-strong and strong.

\subsection{Model Description}

In this paper, we analyse our data using three different types of panel data models.

- Static panel data model via fixed effects and random effects model.

- Dynamic panel data model with autoregressive model via Parks Method.

- Dynamic panel data model with panel moving-average models via Da Silva Method.

Data of the four countries of Malaysia, Indonesia, Thailand and Singapore (cross-section $=4$ ) for the monthly period of 17 years from 1997 to 2013 (time series $=204$ ) is used. Therefore the number of observations would comprise the time series multiplied by the cross section $(4 * 204)=816$ panel observation for our empirical analysis. This demonstrates that a panel data increases the sample size which leads to more robust results as compared to pure time series or cross sectional data. In the fixed effect model, the intercepts may vary across time or groups, but in the random effect model, the error variances may vary across groups and time. The slope is constant in both fixed and random effect model and our key focus area will be only the intercepts and error variances.

Our preliminary analysis includes pooled data models where we pooled the time series and cross section to increase the sample size, without taking consideration of cross-section and time-series behaviour. Panel data is a broader-based concept and most practical and more feasible in the case of handling any economic modeling. The pooled data model is analysed using OLS method of estimation where data is pooled from the time series and cross section data in order to increase the sample size, but do not consider any aspect to cross section and time series issue and behavior and ignore the problem case by pooling the data.

The main difference between fixed effect and random effect models lies the role of dummy variables. If dummy variables act as part of error term, it exhibits random effects, while if it is part of intercept it would exhibit fixed effects. In a fixed effects model, the effects are time invariant and it is considered a part of intercept $\left(\mathrm{u}_{\mathrm{i}}\right)$, which allows it to be correlated to other regressors, but the random effect model assumes that intercept is part of errors and thus it should not be correlated to any regressors, which is one of the core OLS assumptions.

Hausman Specification Test (Hausman, 1978) is used to identify whether the fixed effect or random effect model is the more suitable model for our research analysis in this study. In the Hausman test, the null hypothesis is that the individual effect is uncorrelated with other regressors in the model. If $\mathrm{H}_{0}$ is rejected, we will proceed with the fixed effect model. But if the null hypothesis is accepted, a fixed effect model will produce biased result and thus the 
random effect model is preferred. Further, the fixed effects model will be tested by incremental F-test and random effects will be studied using Lagrange Multiplier (LM) test.

In dynamic panel data analysis, we try to estimate first order autoregressive model with contemporaneous correlation using the Parks method, while the mixed variance component moving average error is estimated using Da Silva method.

\subsection{Model Representation}

In general, we will have the following modeling structure for data analysis using each data type.

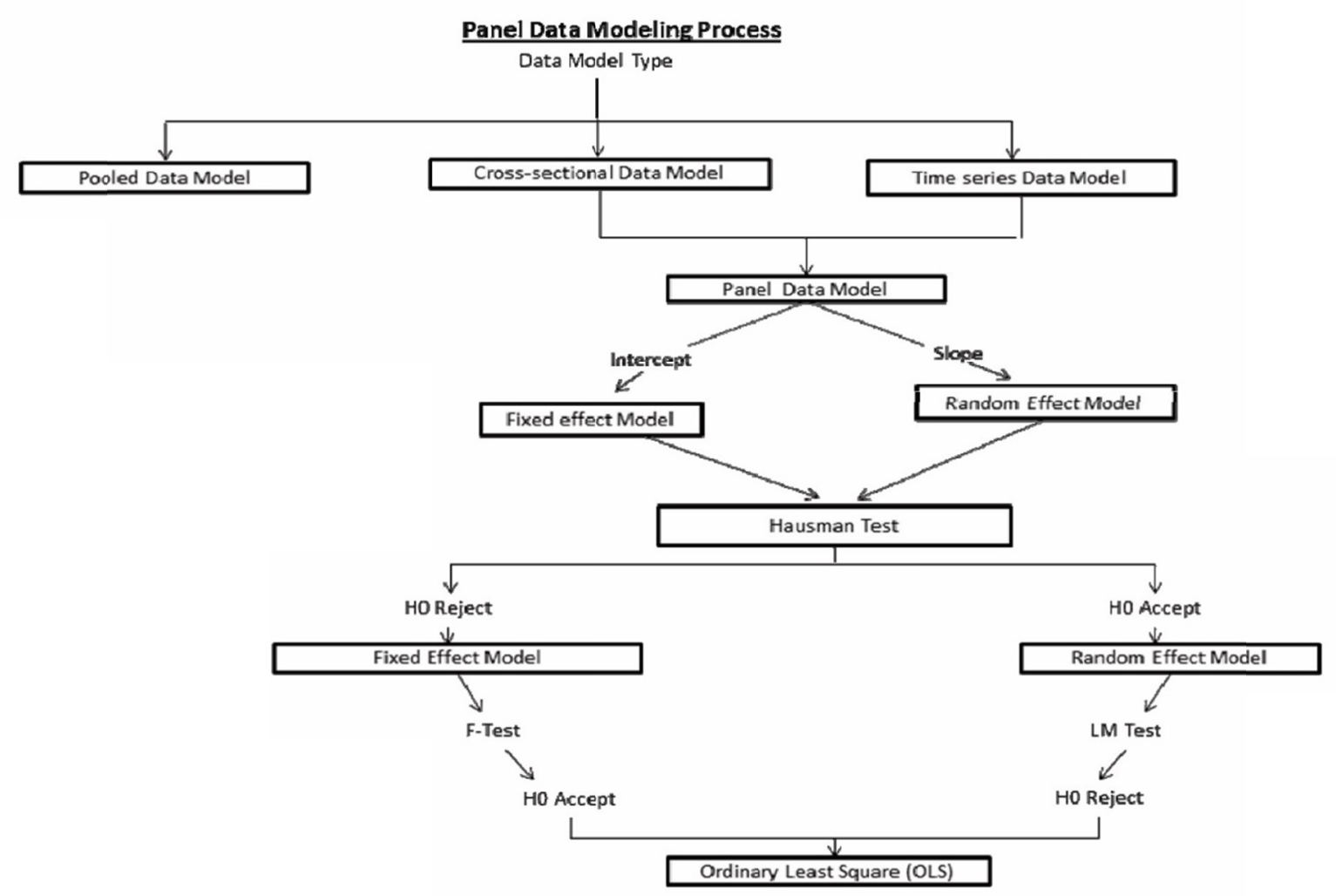

Model with cross sectional data only (time series remain constant):

$$
C S=Y_{i}=B_{0}+B_{1} x_{i}+U_{i}
$$

where $\mathrm{i}=1,2,3, \mathrm{~N}$ :

Model with time series data only (Cross section remain constant):

$$
T S=Y_{t}=B_{0}+B_{1} x_{i}+U_{i}
$$

where $\mathrm{t}=1,2,3, \mathrm{~T}$ :

Model with panel data will be

$$
P D M=Y_{i t}=B_{0 i}+B_{1} x_{i t}+U_{i t}
$$

where $\mathrm{i}=1,2,3, \mathrm{~N}$ : and $\mathrm{t}=1,2,3, \mathrm{~T}$ : and the total simple size will be $\mathrm{N} \mathrm{x}$.

where,

$\mathrm{U}_{\mathrm{it}}=$ Error term effect;

$\mathrm{I}=$ Time series effect;

$\mathrm{T}=$ Cross section effect.

$\alpha\left(=\alpha_{1}, \alpha_{2}, \alpha_{3}, \ldots, \alpha_{n}\right)$ is the intercept parameters $\beta\left(=\beta_{1}, \beta_{2}, \beta_{3}, \ldots, \beta_{n}\right)$, is the slope parameters.

The general framework of panel data model is as follows:

$$
S T K M K T_{i t}=\beta_{0}+\beta 1 W T I_{i t}+\beta_{2} C P I_{i t}+\beta_{3} E X R T_{i t}+\beta_{4} M 1_{i t}+U_{i t}
$$

where: 
1) $\beta_{0}$ is the intercept;

2) $t$ is a time specific effect $(t=1, \ldots . . T)$;

3) I is cross section Specific effect $(I=1 \ldots \ldots . N)$;

4) $U_{i t}$ is the error term effect;

5) STKMKT = Stock market indices;

6) $\mathrm{WTI}=$ West Texas Intermediate;

7) $\mathrm{CPI}=$ Consumer price index;

8) $\quad$ EXRT = Exchange rate;

9) M1 = M1 money supply.

\section{Empirical Results}

In using balanced panel data to estimate the effects of WTI, CPI, EXRT and M1 on STKMKT over the monthly period of 1997-2013 using 816 panel data observations, the correlation between the variables were first derived per Table 1. Results show that both WTI and M1 are moderately correlated to STKMKT at coefficients of 0.5820 and 0.6129 respectively, while CPI is weakly correlated, and EXRT almost not correlated at 0.5150 and 0.1732 respectively.

Table 1. Correlation analysis

\begin{tabular}{cccccc}
\hline \multicolumn{5}{c}{$\begin{array}{c}\text { Pearson Correlation Coefficients, } \mathrm{N}=816 \\
\text { Prob }>|\mathrm{r}| \text { under } \mathrm{H}_{0}: \text { Rho }=0\end{array}$} \\
\hline STKMKT & WTI & CPI & EXRT & M1 \\
\hline STKMKT & 1 & 0.5820 & 0.5150 & 0.1732 & 0.6129 \\
WTI & 0.5820 & 1 & 0.5336 & 0.0323 & 0.4260 \\
CPI & 0.5150 & 0.5336 & 1 & 0.6479 & 0.8880 \\
EXRT & 0.1732 & 0.0323 & 0.6479 & 1 & 0.6990 \\
M1 & 0.6129 & 0.4260 & 0.8880 & 0.6990 & 1 \\
\hline
\end{tabular}

Table 2 below shows that countries all factors of WTI, CPI, EXRT and M1 are highly significant at 1\% (P-value 0.0001 ) for pooled data analysis. P-value test hypothesis is that each coefficient is different from zero. To reject this $p$-value has to be lower than 0.05 . In this case p-value 0.0001 for all factors indicate that the WTI, CPI, EXRT and M1 have effects on the dependent variable of STKMKT. Furthermore, the hypothesis of t-values test is that each coefficient is different from zero. To reject this hypothesis the t-value have to be higher than 1.96 (for a 95\% of confidence). This model is considered a good-fitted model as the R-Square is highly significant (equal or near $1.0)$.

In results of static panel data analysis, we observed that WTI, EXRT and M1 also have significant effects on STKMKT, except for CPI in the fixed one-way model. This may be due to the weak correlation between CPI and STKMKT in the prelimary analysis of correlation. The fixed two-way model showed significant effects of CPI, EXRT and M1, but no results were generated for WTI due to possible multicollinearity issues which would warrant further future investigations. In both fixed one-way and fixed two-way models, we observed significant F-test results which points to the use of these fixed effects model being the rightful model to be applied.

Random effects model were also utilized, where the random-one methodology adopted by Fuller and Battese yielded the observation that WTI, EXRT and M1 have significant effects on STKMKT, except for CPI which was insignificant. The Hausman test also yielded insignificant results that point to the acceptance of fixed-effects model as being more applicable. Extensions with random-two methodology, also by Fuller and Battese, shows similar results. However, in using random-two methodology adopted by Wallace and Hussain showed that CPI was also significant.

In using dynamic panel data analysis of Parks, we noted significant relationship for WTI, CPI and M1, with the exception of EXRT which was insignificant, as shown in Table 3. This is probably due to the almost zero correlation between EXRT and STKMKT. However, the Da Silva method showed significant relationships for all the independent variables of WTI, CPI, EXRT and M1 on STKMKT. 
Table 2. Results of static panel data analysis

\begin{tabular}{|c|c|c|c|c|c|c|c|c|c|}
\hline \multirow[t]{2}{*}{ Variables } & \multicolumn{3}{|c|}{ Pooled data model } & \multicolumn{3}{|c|}{ Fixed One Way } & \multicolumn{3}{|c|}{ Fixed Two Way } \\
\hline & Est. & t-val. & $\operatorname{Pr}>|t|$ & Est. & t-val. & $\operatorname{Pr}>|t|$ & Est. & t-val. & $\operatorname{Pr}>|t|$ \\
\hline Intercept & 1250.337 & 10.75 & $<0.0001$ & 1474.366 & 19.55 & $<0.0001$ & 1968.87 & 12.41 & $<0.0001^{*}$ \\
\hline WTI & 12.108 & 11.96 & $<0.0001^{*}$ & 7.165 & 15.08 & $<0.0001 *$ & - & - & - \\
\hline CPI & -9.126 & -6.7 & $<0.0001 *$ & 1.437 & 1.47 & 0.1416 & 3.731 & 3.96 & $<0.0001^{*}$ \\
\hline EXRT & -0.074 & -7.89 & $<0.0001 *$ & -0.105 & -7.57 & $<0.0001 *$ & -0.054 & -3.88 & $<0.0001^{*}$ \\
\hline M1 & 0.006 & 18.61 & $<0.0001^{*}$ & 0.005 & 20.45 & $<0.0001^{*}$ & 0.004 & 17.52 & $<0.0001^{*}$ \\
\hline R-Square & 0.5786 & & & & & 0.9127 & & & 0.9482 \\
\hline F-Test & & & & & & $<0.0001 *$ & & & $<0.0001^{*}$ \\
\hline \multirow[t]{3}{*}{ Variables } & \multicolumn{3}{|c|}{ Random one } & \multicolumn{3}{|c|}{ Random TWO } & \multicolumn{3}{|c|}{ Random TWO } \\
\hline & \multicolumn{3}{|c|}{ (Fuller and Battese ) } & \multicolumn{3}{|c|}{ (Fuller and Battese ) } & \multicolumn{3}{|c|}{ Wallace and Hussain } \\
\hline & Est. & t-val. & $\operatorname{Pr}>|t|$ & Est. & t-val. & $\operatorname{Pr}>|t|$ & Est. & t-val. & $\operatorname{Pr}>|t|$ \\
\hline Intercept & 457.528 & 0.95 & 0.3402 & 328.185 & 0.63 & 0.5314 & 195.596 & 0.09 & 0.9322 \\
\hline WTI & 7.168 & 15.1 & $<0.0001^{*}$ & 7.123 & 13.3 & $<0.0001^{*}$ & 7.096 & 6.79 & $<0.0001^{*}$ \\
\hline CPI & 1.428 & 1.47 & $01431 *$ & 2.481 & 2.74 & $0.0063^{*}$ & 3.525 & 4.25 & $<0.0001^{*}$ \\
\hline EXRT & -0.105 & -7.62 & $<0.0001 *$ & -0.083 & -6.35 & $<0.0001^{*}$ & -0.059 & 4.83 & $<0.0001^{*}$ \\
\hline M1 & 0.005 & 20.5 & $<0.0001^{*}$ & 0 & 20.3 & $<0.0001 *$ & 0.004 & 20.25 & $<0.0001^{*}$ \\
\hline R-Square & & & 0.8614 & & & 0.8309 & & & 0.7723 \\
\hline F-Test & & & - & & & - & & & - \\
\hline Hausman Test & & & 0.9994 & & & - & & & - \\
\hline
\end{tabular}

Note. *Significant at $5 \%$ level.

Table 3. Results of dynamic panel data analysis

\begin{tabular}{lllllll}
\hline \multirow{2}{*}{ Variables } & \multicolumn{2}{l}{ Parks Method } & \multicolumn{5}{l}{ Da Silva Method } \\
\cline { 2 - 6 } & Estimate & $\mathrm{t}$-value & $\operatorname{Pr}>|\mathrm{t}|$ & Estimate & $\mathrm{t}$-value & $\operatorname{Pr}>|\mathrm{t}|$ \\
\hline Intercept & 12.406 & 0.06 & 0.9545 & -407.681 & -0.74 & 0.4617 \\
WTI & 1.703 & 2.88 & $0.0040^{*}$ & 9.711 & 32.6 & $<0.0001^{*}$ \\
CPI & 5.18 & 3.08 & $0.0022^{*}$ & 9.054 & 142.01 & $<0.0001^{*}$ \\
EXRT & -0.012 & -1.21 & 0.2272 & 0.023 & 32.6 & $<0.0001^{*}$ \\
M1 & 0.002 & 6.94 & $<0.0001^{*}$ & 0.001 & 77.12 & $<0.0001^{*}$ \\
\hline R-Square & 0.1839 & & 0.6003 & & \\
\hline
\end{tabular}

Note. *Significant at 5\% level.

\section{Conclusion}

The aim of this paper is to test the validity of EMH in the contest of the four major ASEAN countries of Malaysia, Indonesia, Thailand and Singapore. From the findings above, we can conclude with a high degree of certainty that crude oil price plays a significant role in influencing the movement of stock market of these countries. Similarly, money supply also has significant role in the determination of stock prices due to the increase in money flow into equities. However, consumer price index and exchange rate do not yield conclusive results of their impact on the stock market prices, which are also backed by literature that shows asymmetric effects of these indicators on the economy. As crude oil price and money supply increases, the stock market indices would be expected to increase, and as such anyone with information of the movement of these variables stand a high chance of making extraordinary gains in the stock market, hence rendering the notion that the EMH is not valid in this circumstances. However, it is hoped that more studies would continue to shed light on the EMH theory.

\section{References}

Abdullah, D. A., \& Hayworth, S. C. (1993). Macroeconometrics of stock price fluctuations. Quarterly Journal of Business and Economics, 32, 50-67.

Apergis, N., \& Miller, S. M. (2009). Do structural oil-market shocks affect stock prices? Energy Economics, 31, 569-575. http://dx.doi.org/10.1016/j.eneco.2009.03.001

Barsky, R., \& Kilian, L. (2004). Oil and macroeconomy since the 1970s. Journal of Economic Perspectives, 18, 115-134. http://dx.doi.org/10.1257/0895330042632708 
Basher, S. A., Haug, A. A., \& Sadorsky, P. (2012). Oil prices, exchange rates and emerging stock markets. Energy Economics, 34, 227-240. http://dx.doi.org/10.1016/j.eneco.2011.10.005

Beechey M. G. D., \& Vickrey, J. (2000). The Efficient Markets Hypothesis: A Survey. Reserve Bank of Australia.

Buguk, C., \& Brorsen, B. W. (2003). Testing weak-form market efficiency: Evidence from the Istanbul stock exchange. International Review of Financial Analysis, 12, 579-590. http://dx.doi.org/10.1016/S1057-5219(03)00065-6

Bjørnland, H. C. (2009). Oil price shocks and stock market booms in an oil-exporting country. Scottish Journal of Political Economy, 56, 232-254. http://dx.doi.org/10.1111/j.1467-9485.2009.00482.x

Chang, K. P., \& Ting, K. S. (2000). A variance ratio test of the random walk hypothesis for Taiwan's stock market. Applied Financial Economics, 20, 525-532. http://dx.doi.org/10.1080/096031000416406

Chang, E. J., Arauio-Lima, E. J., \& Tabak, B. M. (2004). Testing for predictability in emerging equity markets. Emerging Market Review, 5, 295-316. http://dx.doi.org/10.1016/j.ememar.2004.03.005

Charles, A., \& Darne, O. (2009). The random walk hypothesis for Chinese stock markets: Evidence from variance ratio tests. Economic Systems, 33, 117-126. http://dx.doi.org/10.1016/j.ecosys.2008.09.003

Chen, N. F., Roll, R., \& Ross, S. A. (1986). Economics forces and the stock market. Journal of Business, 59, 383-403. http://dx.doi.org/10.1086/296344

Chen, S. S. (2010). Do higher oil prices push the stock market into bear territory? Energy Economics, 32, 490-495. http://dx.doi.org/10.1016/j.eneco.2009.08.018

Chow, V. K., \& Denning, K. D. (1993). A simple multiple variance ratio test. Journal of Econometrics, 58, 385-401. http://dx.doi.org/10.1016/0304-4076(93)90051-6

DeFina, R. P. (1991). Does Inflation Depress the Stock Market? Business Review-Federal Reserve Bank of Philadelphia. Nov/Dec.

Elder, J., \& Serletis, A. (2010). Oil price uncertainty. Journal of Money, Credit and Banking, 42, 1137-1159. http://dx.doi.org/10.1111/j.1538-4616.2010.00323.x

Fama, E. (1965). The Behavior of Stock Market Prices. Journal of Business, 38, 34-105. http://dx.doi.org/10.1086/294743

Fama, E. (1970). Efficient Capital Markets: A Review of Theory and Empirical Work. Journal of Finance, 25(2), 383-417. http://dx.doi.org/10.2307/2325486

Fama, E. F., \& Schwert, W. G. (1977). Asset returns and inflation. Journal of Financial Economics, 5, 115-146. http://dx.doi.org/10.1016/0304-405X(77)90014-9

Fifield, S. G. M., \& Jetty, J. (2008). Further evidence on the efficiency of the Chinese stock markets: A note. Research in International Business and Finance, 22, 351-361. http://dx.doi.org/10.1016/j.ribaf.2008.02.002

Geske, R., \& Roll, R. (1983). The fiscal and monetary linkage between stock returns and inflation. Journal of Finance, 38, 1-33. http://dx.doi.org/10.1111/j.1540-6261.1983.tb03623.x

Gisser, M., \& Goodwin, T. H. (1986). Crude Oil and the Macroeconomy: Tests of Some Popular Notions. Journal of Money, Credit and Banking, 18, 95-103. http://dx.doi.org/10.2307/1992323

Gultekin, N. B. (1983). Stock market returns and inflation. Evidence from other countries. The Journal of Finance, 38, 49-65. http://dx.doi.org/10.1111/j.1540-6261.1983.tb03625.x

Hamilton, J. D. (1983). Oil and the Macroeconomy Since World War II. Journal of Political Economy, 228-248. http://dx.doi.org/10.1086/261140

Hausman, J. A. (1978). Specification Test in Econometrics. Econometrica, 46(6), 1251-1271. http://dx.doi.org/10.2307/1913827

Hoque, H., Jae, H. K., \& Pyun, C. S. (2007). A comparison of variance ratio tests of random walk: A case of Asian emerging stock markets. International Review of Economics and Finance, 16, 488-502. http://dx.doi.org/10.1016/j.iref.2006.01.001

Huang, R., Masulis, R., \& Stoll, H. (1996). Energy shocks and financial markets. Journal of Futures Markets, 16, 1-27. http://dx.doi.org/10.1002/(SICI)1096-9934(199602)16:1<1::AID-FUT1>3.0.CO;2-Q

Hung, J. C. (2009). Deregulation and liberalization of the Chinese stock market and the improvement of market efficiency. The Quarterly Review of Economics and Finance, 49, 843-857. 
http://dx.doi.org/10.1016/j.qref.2009.04.005

Ibrahim, M. H., \& Aziz, H. (2003). Macroeconomic variables and the Malaysian equity market: A view through rolling subsamples. Journal of Economic Studies, 30, 6-27. http://dx.doi.org/10.1108/01443580310455241

Jones, C. M., \& Kaul, G. (1996). Oil and the Stock Markets. Journal of Finance, 51(2). http://dx.doi.org/10.1111/j.1540-6261.1996.tb02691.x

Jung, H., \& Park, C. (2011). Stock market reaction to oil price shocks: A comparison between an oil-exporting economy and an oil-importing economy. Journal of Economic Theory and Econometrics, 22, 1-29.

Karemera, D., Ojah, K., \& Cole, A. J. (1999). Random walks and market efficiency tests: Evidence from emerging equity markets. Review of Quantitative Finance and Accounting, 13, 171-188. http://dx.doi.org/10.1023/A:1008399910942

Kilian, L. (2009). Not all oil price shocks are alike: Disentangling demand and supply shocks in the crude oil market. American Economic Review, 99, 1053-1069. http://dx.doi.org/10.1257/aer.99.3.1053

Kilian, L., \& Park, C. (2009). The impact of oil price shocks on the US stock market. International Economic Review, 50, 1267-1287. http://dx.doi.org/10.1111/j.1468-2354.2009.00568.x

Kim, H. J., \& Shamsuddin, A. (2008). Are Asian stock markets efficient? Evidence from new multiple variance ratio tests. Journal of Empirical Finance, 15, 518-532. http://dx.doi.org/10.1016/j.jempfin.2007.07.001

Khil, J., \& Lee, B. S. (2000). Are common stocks a good hedge against inflation? Evidence from the Pacific-rim $\begin{array}{lllll}\text { countries. } & \text { Pacific-Basin } & \text { Finance } & \text { 857-482), }\end{array}$ http://dx.doi.org/10.1016/S0927-538X(00)00019-6

Lagoarde, S. T., \& Lucey, B. M. (2008). Efficiency in emerging markets: Evidence from the MENA region. International Financial Markets, Institutions and Money, 18, 94-105. http://dx.doi.org/10.1016/j.intfin.2006.06.003

Lee, K., \& Ratti, R. A. (1995). Oil Shocks and the Macroeconomy: The Role of Price Variability. Energy Journal, 16, 39-56. http://dx.doi.org/10.5547/ISSN0195-6574-EJ-Vol16-No4-2

Lee, K., \& Ni, S. (2002). On the Dynamic Effects of Oil Price Shocks: A Study Using Industry Level Data. Journal of Monetary Economics, 49, 823-852. http://dx.doi.org/10.1016/S0304-3932(02)00114-9

Lo, A. W., \& MacKinlay, C. A. (1988). Stock market prices do not follow random walk: Evidence from a simple specification test. Review of Financial Studies, 1, 41-66. http://dx.doi.org/10.1093/rfs/1.1.41

Lo, A. W., \& MacKinlay, C. A. (1989). The size and power of the variance ratio test in finite samples: A Monte Carlo investigation. Journal of Econometrics, 20, 203-238. http://dx.doi.org/10.1016/0304-4076(89)90083-3

Masih, R., Peters, S., \& Mello, L. (2011). Oil price volatility and stock price fluctuations in an emerging market: Evidence from South Korea. Energy Economics, 33, 975-986. http://dx.doi.org/10.1016/j.eneco.2011.03.015

Maysami, R. C., \& Koh, T. S. (2000). A vector error correction model of the Singapore stock market. International Review of Economics and Finance, 9, 79-96. http://dx.doi.org/10.1016/S1059-0560(99)00042-8

Miller, J. I., \& Ratti, R. A. (2009). Crude oil and stock markets: Stability, instability and bubbles. Energy Economics, 31, 559-568. http://dx.doi.org/10.1016/j.eneco.2009.01.009

Mork, K. A., \& Hall, R. E. (1980). Energy Prices, Inflation, and Recession, 1974-1975. The Energy Journal, 1(3), 31-63.

Mork, K. A. (1989). Oil and the Macroeconomy When Prices Go Up and Down: An Extension of Hamilton's Results. Journal of Political Economy, 91, 740-744. http://dx.doi.org/10.1086/261625

Mukherjee, T. K., \& Naka, A. (1995). Dynamic relations between macroeconomic variables and the japanese stock market: an application of a vector error correction model. The Journal of Financial Research, 18, 223-237. http://dx.doi.org/10.1111/j.1475-6803.1995.tb00563.x

Park, J., \& Ratti, R. A. (2008). Oil price shocks and stock markets in the US and 13 European countries. Energy Economics, 30, 2587-2608. http://dx.doi.org/10.1016/j.eneco.2008.04.003

Pierce, J. L., \& Enzler, J. J. (1974). The Effects of External Inflationary Shocks. Brookings Papers on Economic Activity, 1, 13-61. http://dx.doi.org/10.2307/2534072

Rasche, R. H., \& Tatom, J. A. (1977). Energy Resources and Potential GNP. Federal Reserve Bank of St. Louis Review, 59(June), 10-24. 
Sadorsky, P. (1999). Oil price shocks and stock market activity. Energy Economics, 21, 449-469. http://dx.doi.org/10.1016/S0140-9883(99)00020-1

Samuelson, P. (1965). Proof That Properly Anticipated Prices Fluctuate Randomly. Industrial Management Review, 6, 41-49.

Schwert, G. W. (1981). The adjustment of stock prices to information about inflation. The Journal of Finance, 36, 15-29. http://dx.doi.org/10.1111/j.1540-6261.1981.tb03531.x

Shabri, M., Meera, A. K., Aziz, P. P. A., \& Ibrahim, M. (2001). The Relationship Between Stock Returns and Inflation: Evidence From Malaysia and Indonesia. Proceedings of The Malaysia Finance Association Third Annual Symposium. Management Center: International Islamic University Malaysia, 517-547.

Solnik, B. (1983). The relation between stock prices and inflationary expectations: The international evidence. The Journal of Finance, 38, 35-48. http://dx.doi.org/10.1111/j.1540-6261.1983.tb03624.x

Wei, C. (2003). Energy, the stock market, and the Putty-Clay investment model. American Economic Review, 93, 311-323. http://dx.doi.org/10.1257/000282803321455313

Wright, J. H. (2000). Alternative variance-ratio tests using ranks and signs. Journal of Business and Economics Statistics, 18, 1-9.

\section{Copyrights}

Copyright for this article is retained by the author(s), with first publication rights granted to the journal.

This is an open-access article distributed under the terms and conditions of the Creative Commons Attribution license (http://creativecommons.org/licenses/by/3.0/). 